DOI https://doi.org/10.18551/rjoas.2017-12.45

\title{
EFFECTIVENESS OF HUANGLONGBING VECTOR (DIAPHORINA CITRI KUWAYAMA) CONTROL IN CITRUS GROWER GROUP BASED IN SAMBAS REGENCY OF WEST KALIMANTAN, INDONESIA
}

\author{
Supriyanto Arry* \\ Indonesian Citrus and Subtropical Fruit Research Institute, Indonesia \\ Muhammad Zuhran, \\ West Kalimantan Assessment Institute for Agricultural Technology, Indonesia \\ Titiek Purbiati ${ }^{3}$ \\ East Java Assessment Institute for Agricultural Technology, Indonesia \\ *E-mail: arry supriyanto@yahoo.com
}

\begin{abstract}
The purpose of this study was to determine the effectiveness of Huanglongbing vector control based on Citrus Grower Group recommendation. Studies have been carried out in 2010 in Tebas Sungai village, Sambas district, with 11 tangerine groves owned by growers in the Citrus grower Association of Sambas district. The tangerine grove that been used are, one grower's orchard as a demonstration plot in a particular citrus grower group (orchard I); five other citrus orchards with different ownership at the same citrus grower Group (orchard II), as well as five other citrus orchard with different ownership which each of them spreads over five different citrus grower groups outside the farm demonstration plots (orchard III). The recommendation technology for controlling Huanglongbing vector which applied in this experiment, included bark painting by systemic insecticide of imidacloprid for two each 1.5month and spray using contact insecticide with dimethoate to the plant crown which application time been alternated after bark painting application. The effectiveness of technology implementation is measured by a decrease psyllid populations found in citrus samples in adult stage, nymphs and eggs that were observed at regular intervals every two weeks during the flushing to the 14th week after the first treatment. The results showed that recommended treatment technology were absolutely proven to reduce Huanglongbing vector population in significant, namely in the orchard I, II, and III respectively at $95.3 \%, 84.7 \%$, and $72 \%$ for stage adult; $97.3 \%, 80 \%$, and $100 \%$ for stage nymphs; and $98.5 \%, 100 \%$ and $100 \%$ for the egg stage.
\end{abstract}

\section{KEY WORDS}

Citrus, Huanglongbing, control, citrus grower group.

The sustainability of citrus agro business in Sambas district, West Kalimantan, Indonesia, which is an important center of citrus production in Indonesia had faced serious threats because of the Citrus vein phloem disease Degeneration (CVPD) international named of Huanglongbing (HLB). In 2009, Citrus Center, located in Terbas-Sambas reported at least $30 \%$ of the citrus crop in Sambas district has been infected with this deadly disease. The slow response from the local government to against any offensive of HLB disease made the citrus trees condition getting worse and causing many citrus trees dead. Basically, in 2007 Research Institute for Citrus and Subtropical Fruits reported that some citrus trees in Sambas district positively infected by HLB, found a lot of its vector, psyllids of D.citri that positively some of them were detected contained of HLB pathogens (Supriyanto, et al., 2007).

HLB pathogen is Canditatus Liberibacter asiaticum (Jagoueix et al. 1996; Hocquellet et al. 1999) which can be transmitted by an insect namely Diaphorina citri and through propagating method which the buds used had been infected by HLB. To avoid increasing the 
amount of loss, the HLB disease control measures should be done properly including its vectors. According to the Local Extension of Agriculture and Livestock at Sambas, in 2007, the number of citrus trees in this area was $11,820.95$ ha and in 2010 become $9,364.38$ ha, It means the death trees caused by HLB reached had around 2,456.57 ha or $20.8 \%$ equivalent of 50.000 tons of fruit coasted of Rp. 150 billion or US\$156,250. The loss caused by HLB disease affected decreasing of citrus production, growers income, employment in citrus agro business ( esp. orchard labors, crop carrier labor, collectors fruit labor, basket fruit makers, etc ), economic, and potentially able to erase Sambas image as major citrus producer in Indonesia.

HLB disease can be controlled by applying Integrated Health Management for Citrus Orchard (IMCHO) (Supriyanto, 2008; Supriyanto, et al., 1999,) consisting of five technology component which must be applied correctly and simultaneously, ie (1). By using budded trees labeled (Supriyanto and Whittle 1992; Supriyanto et al., 1998; (2). HLB effective vector control (Nurhadi and Whittle, 1998; Wuryanti et al., 2004; Dwiastuti et al., 2004); (3). Eradicates HLB disease plants (Dwiastuti et al., 2003), (4). An optimal plant maintenances, and (5). Consolidating application of those technology components in the production centers (Supriyanto, 2008). The existing technology component must be improved according to the result of technology innovation which fit with the specific conditions in the target location. HLB vector control repair by using its natural enemies, and intercropping with guava (Dwiastuti et al., 2007; Wuryantini and Endarto, 2008; Pustika, et al., 2008).

In general, citrus growers joined to citrus grower groups which had orchards adjacent to each other. This citrus grower groups usually consist of 20-30 growers, and the adjacent citrus grower groups joined to become clustered citrus grower groups, and later after well developed, they will formulate Citrus Agro business Association. Although it has not been tough, farmer institution is expected to increase cohesiveness and togetherness citrus farmers in HLB disease control, especially in the application of IMCHO technology components. The understanding of HLB disease control and its measures for citrus grower group members and assisting them how to apply the recommended technology could increase the effectiveness of HLB disease control especially for its vector.

\section{METHODS OF RESEARCH}

This study was done in 2010-2011 at the village of Tebas Sungai, district of Tebas, Sambas regency in West Kalimantan, Indonesia. This district was the most important citrus area in Sambas in term of the citrus tree number which was almost $50 \%$ of total population in Sambas around 11,000 ha, and around $26.8 \%$ of trees were infected by HLB disease with a lot number of D.citri found. The study was conducted in six citrus grower groups who were the members of clustered citrus grower groups namely Mekar Bersatu. The treatment of recommend technology oof HLB vector control were implemented in 11 orchards which divided into 3 groups, following: (1). Orchard I, it consisted of one selected farmer's orchard owned by Zaini with 1 ha large located in one of the farmer groups, namely Chandra Kencana, (2). Orchard II, composed of 5 orchards with different citrus growers ownership which on the same of citrus grower groups of Chandra Kirana, and (3). Orchard III, composed of 5 orchards with different ownership, and each separated in 5 other citrus grower groups but it still be in the clustered citrus grower group of Mekar Bersatu. Those were Kencana Chandra, Chandra Makmur, Chandra Karya, Ilham Bersatu I and Ilham Bersatu II. All citrus grower groups used in this study were located neighbored each other.

Recommended technology of controlling HLB vector of D.citri applied were bark painting used concentrated systemic insecticide contain of an active ingredient of imidacloprid without diluted in 2 times each 1.5 months interval with volume corresponding to trunk diameter was about 5-10 cc (Dwiastuti et al., 2004). In addition, it was also sprayed by contact insecticide with dimethoate active ingredient using recommended doses of $2 \mathrm{cc} / \mathrm{l}$ (Wuryantini et al, 2004). Time application was depending on the present of D.citri after first bark painting and before the second one. Bark painting were applied at week $0^{\text {th }}$ and $6^{\text {th }}$ while trunks while spraying by a contact insecticide applied at weeks $4^{\text {th }}$ and $10^{\text {th }}$. 
In Orchard I, HLB vector control technology was applied completely to all 500 trees followed by fertilizing of compose of Petrotek $25 \mathrm{~kg} /$ tree, 375 gram of NPK 15-15-15, 375 gram of urea, 405 gram of $\mathrm{KCl}$, foliar spraying, pruning, weeding and mulching, and drainage maintenance. On the citrus trees in orchard II, the owners were assisted to apply bark painting and spraying for HLB vector control and others like applied on orchard I but only on 25 trees of 70-135 tree growers belonged. The trees remain hopefully were continuing conducted and participated by citrus growers by themselves because they have understood how to control the HLB vectors and HLB disease. For orchard III, the citrus growers were just given all the maintenances material needed for 25 trees and let they applied the recommended technology based on their understanding for controlling the vectors of HLB and HLB disease.

Citrus growers participated in this research had joined a training namely SL-PHT or Citrus Field School of Integrated Pest Management with 12 times two week meetings of citrus orchard management stressing on HLB vector control. The citrus growers also had additional counseling by Province Assessment Institute for Agricultural Technology, local field extension and field pest observers staffs in order to emphasis how to control HLB disease and the vector of HLB disease (Subarna, Trisna, A. Ruswandi, dan Darojat. 2007). It was also the role of citrus grower groups to implemented properly of controlling this deadly disease-transmitting insects. Orchard I received completely recommended technology were used as demo plot and for practical purposed of field school. Effectiveness of technology implementation measured by reduction of D.citri of imago stage, nymphs and eggs on sample trees. The number of plants sampled were 25 trees set diagonally. The population of psyllids of adults stage, nymphs and eggs were observed periodically every 2 weeks starting from flushing time and presenting of psyllids of D.citri to 14 weeks after recommended technology applied.

\section{RESULTS AND DISCUSSION}

Citrus trees performances on orchard I which was applied completely recommended technology by researchers was significantly different to those trees on orchard II and III where the recommended technology was applied based on their understanding of how to control the HLB disease they learnt during field school program. Abundant new flushes grown on citrus trees on orchard I and some of them followed by flower bloom compared to those on two other orchards because of different levels of input material applied to those orchards. On the orchard II and II, growers were given i.e. compos and fertilizer, only for 25 trees and let they provided to the rest trees of their orchards (Ridwan, et al., 2008; Ruswandi, et al., 2008.)

On first observations before applying the recommended technology, the number of imago or adult stage of D.citri population had varied among orchards due to the number flushes produced on different level of maintenances by citrus growers. Number of psyllids found on orchard I reached 107 adult stages, while the average imago of D.citri in orchard II were 33, and on orchard III were 5 adult stages . Orchard I also functioned as demo plot of 1 ha consisted of about 500 citrus trees, being optimally maintained by recommended technology. After 14 weeks post-application, number of HLB vectors of D.citri on adult stage could be reduced to $1-5$ psyllids per trees (Table 1 ). It meant, the application recommended technology absolutely able to reduce imago of D.citri population in each Orchard I,II, and III at $95,3 \%, 84,7 \%$, and $72 \%$. The pattern of imago of HLB vectors decreased after applying recommended technology was relative similar to Orchard II, but in Orchard III, the number of D. citri went down till 1 psyllid after first bark painting (Figure 1).

The population of D.citri nymph on first observation in orchard I reached 74 nymphs / tree, orchard II are 22 nymphs / tree, while in orchard III just 1 nymph / tree. The difference of nymph number per tree was also affected by the number of flush produced. At weeks 8th, the nymph boom still fluctuated and tend to decrease with unknown caused even the number of psyllid eggs were reduced significantly (Table 2). The recommended technology were going effective for nymph reduced at weeks of 12 th until $14^{\text {th }}$ (Table 2$)$. The D.citri nymphs 
decreased number compared with first application were 97,3 \% ( orchard I ) and $80.0 \%$ ( orchard II ), while on orchard III still remains 1 nymph per tree.

Table 1 - Average of number population of adult stage of $D$.citri / tree

\begin{tabular}{|c|c|c|c|c|c|c|c|c|}
\hline \multirow{2}{*}{ Locations } & \multicolumn{9}{|c|}{ Weeks after treatments } \\
\cline { 2 - 9 } & 0 & 2 & 4 & 6 & 8 & 10 & 12 & 14 \\
\hline Orchard I & $107 \mathrm{a}$ & $65 \mathrm{a}$ & $65 \mathrm{a}$ & $51 \mathrm{a}$ & $3 \mathrm{~b}$ & $50 \mathrm{a}$ & $11 \mathrm{a}$ & $5 \mathrm{a}$ \\
\hline Orchard II & $32,6 \mathrm{~b}$ & $13,2 \mathrm{~b}$ & $28,2 \mathrm{~b}$ & $13,2 \mathrm{~b}$ & $7,8 \mathrm{~b}$ & $8,2 \mathrm{~b}$ & $4,4 \mathrm{a}$ & $5 \mathrm{a}$ \\
\hline Orchard III & $5 \mathrm{~b}$ & $1 \mathrm{~b}$ & $1 \mathrm{~b}$ & $1 \mathrm{~b}$ & $1 \mathrm{~b}$ & $1 \mathrm{~b}$ & $1 \mathrm{a}$ & $1 \mathrm{a}$ \\
\hline
\end{tabular}

Note: Number followed by different letter in the same column are significant different of $5 \%$ level.

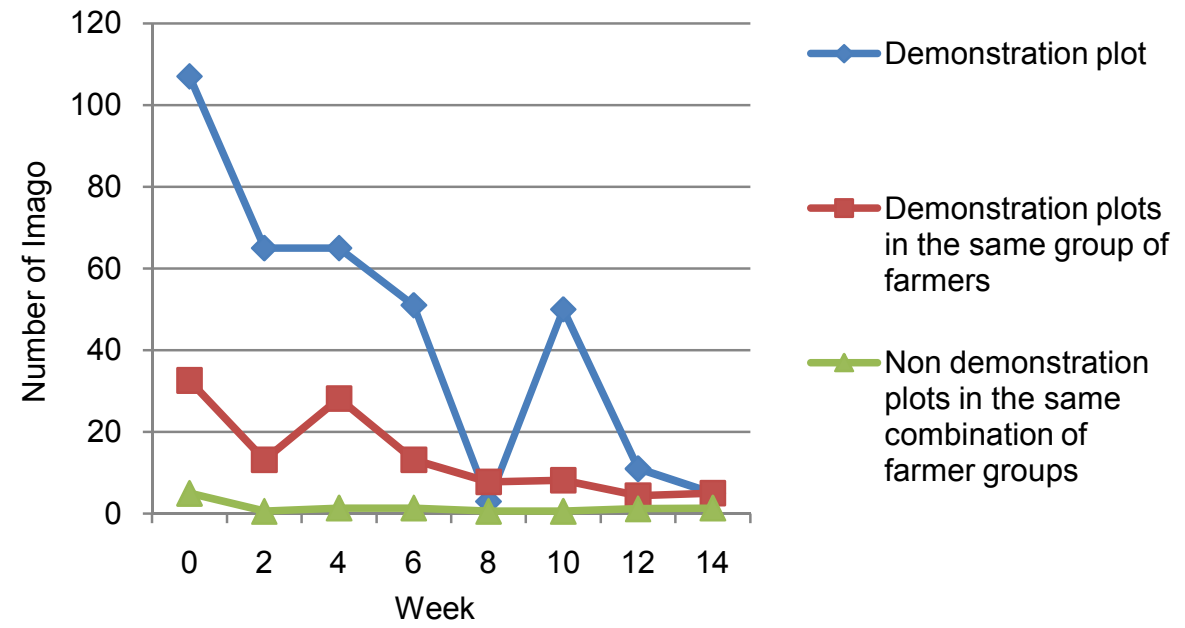

Figure 1 - Pattern of decreasing number of $D$.citri imago 14 weeks after application of the technology

Table 2 - Average of number of $D$.citri nymphs per tree 14 weeks after treatments

\begin{tabular}{|c|c|c|c|c|c|c|c|c|}
\hline \multirow{2}{*}{ Locations } & \multicolumn{9}{|c|}{ Week after treatments } \\
\cline { 2 - 9 } & 0 & 2 & 4 & 6 & 8 & 10 & 12 & 14 \\
\hline Orchard I & $74 a$ & $127 a$ & $3 b$ & $4 b$ & $2 b$ & $97 a$ & $5 b$ & $2 b$ \\
\hline Orchard II & $22 \mathrm{~b}$ & $15 \mathrm{~b}$ & $67 \mathrm{~b}$ & $7 \mathrm{~b}$ & $23 \mathrm{a}$ & $4 \mathrm{~b}$ & $2 \mathrm{~b}$ & $4 \mathrm{~b}$ \\
\hline Orchard III & $1 \mathrm{~b}$ & $1 \mathrm{~b}$ & $11 \mathrm{~b}$ & $1 \mathrm{~b}$ & $1 \mathrm{~b}$ & $0 \mathrm{~b}$ & $0 \mathrm{~b}$ & $1 \mathrm{~b}$ \\
\hline
\end{tabular}

Note: Number followed by different letter in the same column are significant different of $5 \%$ level.

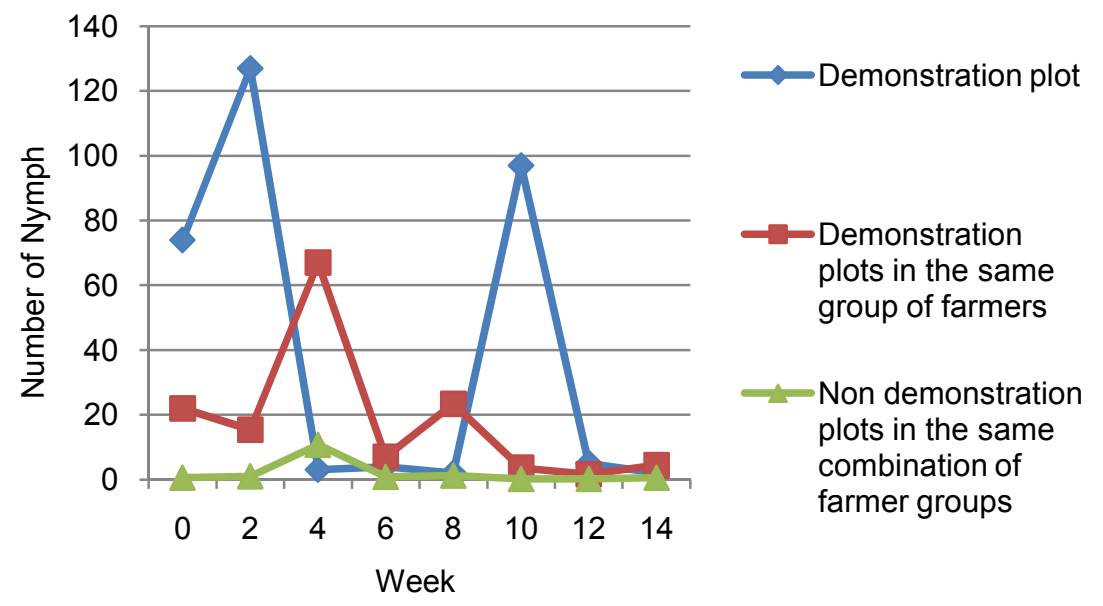

Figure 2 - Pattern of decreasing number of $D$.citri nymphs 14 weeks after application of the technology 
The large amount of imagos and nymphs of D.citri in orchard I were coincided with the number of its eggs, because flushing period was good condition for D.citri done their activities i.e. feeding, copulation, and lying their eggs. The number of psyllid eggs in each of orchard I, II, and III were 135; 25; and 4 per tree respectively (Table 3 and Figure 3). The recommended technology had proven effectively in reducing number of psyllid eggs in undirect way. Fact shown that the number of eggs at weeks $14^{\text {th }}$ were going down up to 98.5\% (orchard I), 100\% (orchard II) and 100\% (orchard III). Eggs will become nymph then imago which they could be weakened by insecticides used by recommended technology for controlling of D.citri. The neighbouring orchard in which had not applied the package of recommended technology would unable to hold psyllids migration, therefore the amount of adult stage of $D$.citri would never be reduced to zero. The active systemic insecticide contained imidacloprit is effectively against bugs such as D.citri and its nymph (in stadium 3 , 4 and 5) but less effective for its eggs (Figure 1-3).

Table 3 - Average of number of D.citri eggs per tree 14 weeks after treatment

\begin{tabular}{|c|c|c|c|c|c|c|c|c|}
\hline \multirow{2}{*}{ Locations } & \multicolumn{9}{|c|}{ Week after treatments } & \multicolumn{1}{c|}{12} & 14 \\
\cline { 2 - 9 } & 0 & 2 & 4 & 6 & 8 & 10 & 12 & $2 \mathrm{~b}$ \\
\hline Orchard I & $135 \mathrm{a}$ & $119 \mathrm{a}$ & $11 \mathrm{~b}$ & $5 \mathrm{~b}$ & $0 \mathrm{~b}$ & $3 \mathrm{~b}$ & $5 \mathrm{~b}$ \\
\hline Orchard II & $25 \mathrm{~b}$ & $20 \mathrm{~b}$ & $4 \mathrm{~b}$ & $0 \mathrm{~b}$ & $1 \mathrm{~b}$ & $0 \mathrm{~b}$ & $0 \mathrm{~b}$ & $0 \mathrm{~b}$ \\
\hline Orchard III & $4 \mathrm{~b}$ & $7 \mathrm{~b}$ & $0 \mathrm{~b}$ & $0 \mathrm{~b}$ & $0 \mathrm{~b}$ & $0 \mathrm{~b}$ & $0 \mathrm{~b}$ & $0 \mathrm{~b}$ \\
\hline
\end{tabular}

Note: Number followed by different letter in the same column are significant different at $5 \%$ level.

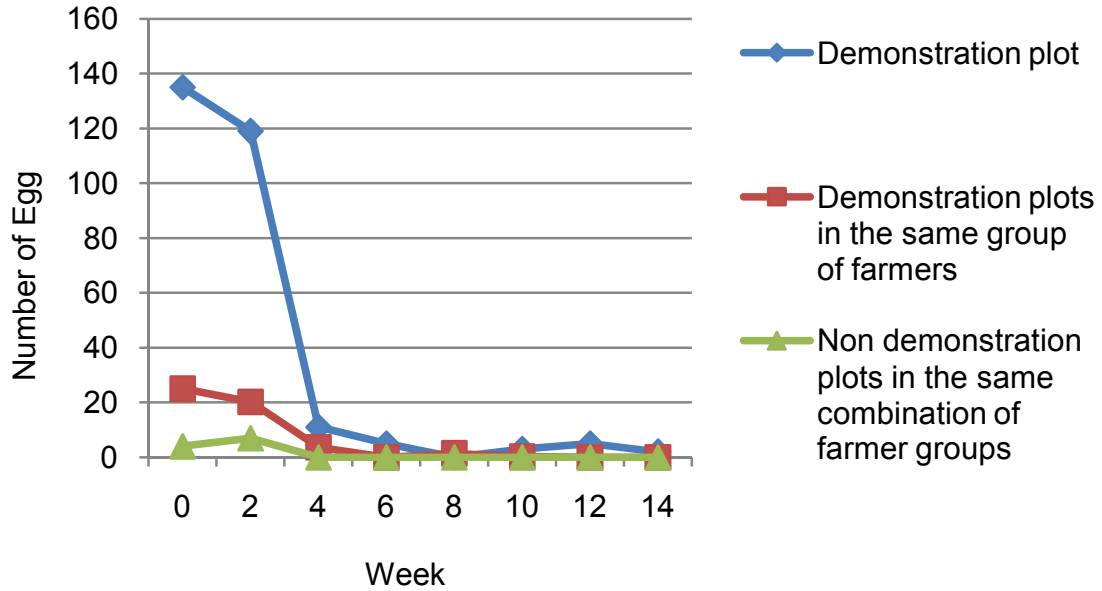

Figure 3 - Patern of decreasing number of D.citri eggs 14 weeks after application of the technology

In orchard I showed that application of bark painting could reduced amount of imago and nymph of D.citri. Two weeks after first bark painting applied, the number of nymphs tended to increase because the nymph eggs starting hatched. At weeks $8^{\text {th }}$, amount of imagos and nymphs of HLB vectors were going down then arised again at weeks $10^{\text {th }}$. That phenomenon's related to the persistency of imidacloprit inside the tissue plant which lasted for about four weeks

The consistency of citrus growers and their citrus grower groups to apply the recommended technology for controlling $D$.citri depend on intensively level understanding of citrus growers how to controll $D$. citri . Orchard I which was functioned as demo plot had good performance in reducing number of imago, nymph, and D.citri eggs and It had the same pattern with those performed in orchards II. Meanwhile, the difficulties faced in orchard III, because it has owned by different citrus grower groups and made difficult to organized in applying components technology for controlling HLB vectors. The control of D.citri was effectively if could be carried out by all member of citrus grower group compactly (Endarto et al, 2006). 


\section{CONCLUSION}

Recommended technology of HLB vector controll was proven effectively to reduce significantly number of adult stage, nymphs, and egg of $D$.citri. As a technology area based, its application become more effective, if it was applied in the same time among citrus growers. Counseling and guideline of recommended technology implementation citrus grower groups based were needed in order to accelerate the tehnology adoption.

\section{REFERENCES}

1. Dwiastuti, M.E., A Twiratno, \& U.N Taflikah. 2003. Hubungan gejala blotching, defisiensi $\mathrm{Zn}$ dan Fe dengan hasil deteksi penyakit CVPD jeruk dengan polymerase chain reaction (Relation of blotching, $\mathrm{Zn}$ and Fe deficiency symptoms and the result of quick detection of CVPD by polymerase chain reaction). Jurnal Hortikultura. J. Hort. 13 (2): 131-137.

2. Dwiastuti, M.E \& M.Y. Kurniwati. 2007. Kefektifan Entomopatogen Hirsitulla citriformis (Deuteromycetes: Moniliales) pada Kutu Psyllid Diaphorina citri Kuw. J.Hort. vol 17(3): 244-252

3. Nurhadi \& A.M. Whittle, 1988. Pengenalan dan Pengendalian Hama dan Penyakit Tanaman Jeruk. Sub Balithorti Malang.

4. Endarto, O., A. Supriyanto, S. Wuryantini \& Anang Triwiratno. 2006. Evaluasi Penerapan Pengelolaan Terpadu Kebun Jeruk Sehat (PTKJS) pada Daerah Endemis CVPD. In M. Winarno, A. Supriyanto, M.E. Dwiastuti \& L. Setyobudi (Eds.). Proceeding, Seminar Nasional Jeruk Tropika Indonesia 2005. hal 277 - 295.

5. Endarto, O., S. Wuryatini. 2010. Pengaruh Lama Peredaman Ekstrak Serbuk Biji Mimba terhadap Kutu Sisik (Aonidiella auranti Maskell (Homoptera:Diaspididae) pada Jeruk Siam (Citrus Suhuiensis Tan.) In Utama, I.M.S., A.D. Susila, R. Poerwanto, N.S. Atara, N.K. Putra, \& K.B. Susrusa (Eds.). Proceeding, Seminar Nasional Hortikultura Indonesia 2010, pp. 683-689

6. Hocquellet, A., Toorawa, P., Bove, J.M., Garnier, M., 1999. Detection and identification of the two Candidatus Liberobacter species associated with citrus huanglongbing by PCR amplification of ribosomal protein genes of the h operon. Mol. Cell. Probes 13, 373-379.

7. Jagoueix, S., Bove', J.M., Garnier, M., 1996. PCR detection of the two Candidatus Liberobacter species associated with greening disease of citrus. Mol. Cell. Probes 10, 43- 50.

8. Pustik, A.B., M.E. Purwanto, S. Subandiyah \& GAC. Beattie. 2008. Insidensi Diaphorina citri dan CVPD pada Tanaman Jeruk Interplanting Jambu Biji. In M. Winarno, Sabari, S. Subandiyah, L. Setyobudi \& A. Supriyanto (Eds.). Proceeding, Seminar Nasional Jeruk 2007, pp. $371-376$

9. Ridwan, H.K., A. Ruswandi, Winarno, A. Muharam, \& Hardiyanto. 2008. Sifat Inovasi dan Aplikasi Teknologi Pengelolaan Terpadu Kebun Jeruk Sehat. J.Hort vol. 18(4): 477-490.

10. Ruswandi, A., A. Muharam, H. Ridwan, Sabari, \& S.B. Rofik. 2008. Tingkat Adopsi Teknologi Pengelolaan Terpadu Kebun Jeruk Sehat (PTKJS). In M. Winarno, Sabari, S. Subandiyah, L. Setyobudi \& A. Supriyanto (Eds.). Proceeding, Seminar Nasional Jeruk 2007, pp. 75-86.

11. Subarna, Trisna. 2007. Sifat Inovasi Teknologi Dalam Pengendalian Serangga Penular CVPD In M. Winarno, Sabari, S. Subandiyah, L. Setyobudi \& A. Supriyanto (Eds.). Proceeding, Seminar Nasional Jeruk 2007, pp. 110-119.

12. Supriyanto, A. and A.M. Whittle. 1992. Citrus Rehabilitation in Indonesia. In R.H. Brlansky, R.F. Hee and L.W. Timmer (edts.) Proc. 11th Conf. of IOCV. p : 409-413

13. Supriyanto, A., A. Triwiratno, \& O. Endarto. 2007. Evaluasi Serangan Penyakit CVPD dan Hama penting Lainnya di Kabupaten Sambas, Kalimantan Barat. Research Report. Balitjestro. $28 p$

14. Supriyanto. A, M.E. Dwiastuti, A. Triwiratno, O. Endarto \& Sutopo. 1999. Pengendalian penyakit CVPD dengan Penerapan Pengelolaan Terpadu Kebun Jeruk Sehat. Manual Procedures, BPTP Karangploso: pp. 23-31. 
15. Supriyanto, A., Setiono, O. Endarto \& A. Triwiratno. 1998. Rakitan Teknologi Produksi Bibit Jeruk Bebas penyakit. In M. Sugiyarto, E. Widayati, W. Istuti, Yulfah, D. Setyorini \& S. Chanafi (Eds.). Monograf Rakitan Teknologi. BPTP Karangploso, Malang, pp. 69-79.

16. Supriyanto, A., Subijanto P. Becu \& A.M. Whittle. 1992. The Indonesian Citrus Improvement Programme. In L. Setyobudi, F.A. Bahar, M. Winarno and A.M. Whittle (eds.). Proc. Asian Citrus Rehab. Conf.

17. Supriyanto, A. 2008. Model Pengembangan Agribisnis Kebun Jeruk Rakyat. In M. Winarno, Sabari, S. Subandiyah, L. Setyobudi \& A. Supriyanto (Eds.). Proceeding, Seminar Nasional Jeruk 2007, pp. 31 - 46.

18. Wirawan, I Gede Putu. 2004. Kemajuan Penelitian Bioteknologi Penyakit CVPD. In Marwoto, B., Hardiyanto, Mutia Erti Dwiastuti, Arry Supriyanto, \& Liliek Setyobudi (Eds.). Proceeding, Seminar Jeruk Siam Nasional, pp. 39-56.

19. Wuryantini, S., O. Endarto, Sukadi, \& R.C. Wicaksono. 2004. Efektifitas Beberapa Insektisida Dimetoat dalam Pengendalian Kutu Loncat Jeruk Diaphorina citri Kuw. In Marwoto, B., Hardiyanto, Mutia Erti Dwiastuti, Arry Supriyanto, \& Liliek Setyobudi (Eds.). Proceeding, Seminar Jeruk Siam Nasional, pp. 307-313. 